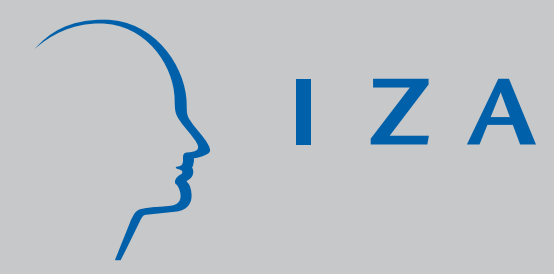

IZA DP No. 1089

The Effects of the Minimum Wage in the Formal and Informal Sectors in Brazil

Sara Lemos

March 2004 


\title{
The Effects of the Minimum Wage in the Formal and Informal Sectors in Brazil
}

\author{
Sara Lemos \\ University of Leicester \\ and IZA Bonn
}

\section{Discussion Paper No. 1089 \\ March 2004}

\author{
IZA \\ P.O. Box 7240 \\ 53072 Bonn \\ Germany \\ Phone: +49-228-3894-0 \\ Fax: +49-228-3894-180 \\ Email: iza@iza.org
}

\begin{abstract}
Any opinions expressed here are those of the author(s) and not those of the institute. Research disseminated by IZA may include views on policy, but the institute itself takes no institutional policy positions.

The Institute for the Study of Labor (IZA) in Bonn is a local and virtual international research center and a place of communication between science, politics and business. IZA is an independent nonprofit company supported by Deutsche Post World Net. The center is associated with the University of Bonn and offers a stimulating research environment through its research networks, research support, and visitors and doctoral programs. IZA engages in (i) original and internationally competitive research in all fields of labor economics, (ii) development of policy concepts, and (iii) dissemination of research results and concepts to the interested public.
\end{abstract}

IZA Discussion Papers often represent preliminary work and are circulated to encourage discussion. Citation of such a paper should account for its provisional character. A revised version may be available on the IZA website (www.iza.org) or directly from the author. 
IZA Discussion Paper No. 1089

March 2004

\title{
ABSTRACT
}

\section{The Effects of the Minimum Wage in the Formal and Informal Sectors in Brazil}

The minimum wage literature is very limited on empirical evidence for developing countries. This already limited literature is even more limited on the effects of the minimum wage in the informal sector, where most of the poor are. Extending the understanding of minimum wage effects both in developing countries and in particular in the informal sector is crucial if the minimum wage is to be used as a policy to help poor people in poor countries. This paper estimates wage and employment effects, accounting for sorting into the formal and informal sectors. The data used is a monthly Brazilian household survey from 1982 to 2000 at individual and regional levels. The formal and informal sectors employment effects were both found to be negative, consistent with the presence of a large spike, substantial spillover effects, and the associated compression effect in the wage distribution of both sectors. This suggests a downwards sloping labour demand curve in both sectors, challenging the standard Two Sectors Model as inadequate to explain the effect of the minimum wage on the formal and informal sectors in Brazil and in Latin America more generally.

JEL Classification: J38

Keywords: minimum wage, wage effect, employment effect, informal sector, Brazil

\author{
Sara Lemos \\ Economics Department \\ University of Leicester \\ University Road \\ Leicester LE1 7RH \\ United Kingdom \\ Tel.: +44 1162522480 \\ Fax: +44116252 2908 \\ Email: sl129@leicester.ac.uk
}




\section{Introduction}

The minimum wage literature is very limited on empirical evidence for developing countries. This already limited literature is even more limited on the effects of the minimum wage in the informal sector, where most of the poor are. Studying the minimum wage effects in the informal sector will give an indication of whether or not, and with what effectiveness, the minimum wage legislation reaches those who could benefit most from antipoverty and anti-inequality policies. Extending the understanding of minimum wage effects both in developing countries and in particular in the informal sector is crucial if the minimum wage is to be used as a policy to help poor people in poor countries.

This paper estimates wage and employment effects in both the formal and informal sectors. The data used is a monthly Brazilian household survey from 1982 to 2000 at individual and regional levels.

Wage effects have been found to be positive in the international (mainly US) literature, larger at lower percentiles, compressing the wage distribution (Brown, 1999; Card and Krueger, 1995), but employment effects have not always been found to be negative, as predicted by standard theory. For example, Neumark and Wascher (1992 and 2000), Deere et al. (1995 and 1996), Currie and Fallick (1996) and Burkhauser et al. (2000), among others, found negative employment effect; whereas Card and Krueger (1995 and 2000), Machin et al. (2003), Machin and Manning (1994), and Dickens et al. (1999), among others, found non-negative effects.

The limited evidence for Latin America suggests that the compression effect is a lot stronger in developing than it is in developed countries, and as a result, adverse employment effects are also stronger (Reynolds and Gregory, 1965; Rottenberg, 1981; Corbo, 1981; Gregory, 1981; CastilloFreeman and Freeman, 1992; Bell, 1997; Lora and Henao, 1997; Villarreal and Samaniego, 1998; Feliciano, 1998; Gindling and Terrell, 2001; El-Hamidi and Terrell, 2001; Angel-Urdinola, 2002; Cowan et al., 2003; Maloney and Mendez, 2003; Montenegro and Pages, 2004). However, more evidence is needed to confirm this reading. That is because there are very few point estimates to rely on, the variance across the range of estimates is high (due to substantial institutional differences across countires), and the estimates might not be directly comparable.

For example, although the evidence for Brazil also suggests that the minimum wage strongly compresses the wage distribution, it suggests a small adverse employment effect (Velloso, 1988; Carneiro and Faria, 1998; Carneiro and Hanley, 2001; Barros and Lemos, 1998; Neri, 1997; Carneiro, 2000 and 2002; Foguel et al., 2000 and 2001; Corseuil and Morgado, 2001; Fajnzylber, 2001; Soares, 2002; Corseuil and Servo, 2002; McIntyre, 2002; Neumark et al., 2003; Lemos, 2004). The studies that 
estimate minimum wage effects across sectors report larger wage effects for the informal than for the formal sector, and mixed employment effect evidence, which was found to be negative in both sectors (Fajnzylber, 2001; Foguel, 1997), and was also negative in the formal and positive in the informal sector (Carneiro; 2000).

Further to utilizing under-explored Brazilian data to provide empirical evidence on the effects of the minimum wage for a key developing country across sectors, this paper also contributes to the Brazilian and international literature in a number of ways. For example: it estimates the effect of the minimum wage throughout the wage distribution in each sector; and it decomposes the total employment effect of the minimum wage into hours and jobs effects in each sector.

The formal and informal sectors employment effects were both found to be negative, consistent with the presence of a large spike, substantial spillover effects, and the associated compression effect in the wage distribution of both sectors. This suggests a downwards sloping labour demand curve in both sectors, challenging the standard Two Sectors Model as inadequate to explain the effect of the minimum wage on the formal and informal sectors in Brazil and in Latin America more generally.

This paper is organized as follows. Section 2 discusses the data on the minimum wage (Section 2.1) and on wages and employment (2.2). Section 3 estimates wage effects, starting with the model specification and identification (Section 3.1) and then the discussion of the results (Section 3.2). Section 4 estimates employment effects, again starting with the model specification (Section 4.1) followed by the discussion of the results (Section 4.2) and robustness checks (Section 4.3). Section 5 contrasts the empirical evidence with the standard theory predictions and Section 6 discusses the associated policy implications. Section 7 concludes.

\section{Data and Descriptive Analysis}

\subsection{Minimum Wage}

The minimum wage in Brazil is national and coverage is full. ${ }^{1}$ Graphs 1.a and 1.b show the nominal and real minimum wage between 1982 and 2000. The real minimum wage shows a negative trend, confirming its erosion over time. This erosion was mainly due to the adjustments of the nominal minimum wage being subject to the rules of successive stabilization plans. For example, in early 1986, the minimum wage was increased by $15 \%$ and bi-annually adjusted initially, but then adjusted

\footnotetext{
${ }^{1}$ Accommodation and food costs can be deducted from the wage. That might account for some below minimum wage workers, although the majority of those are informal sector workers.
} 
whenever inflation was higher than $20 \%$. Despite of that, the minimum wage was $25 \%$ lower in mid 1987 than in early 1986, when it was initially frozen for three months before it was indexed monthly by past inflation. In early 1989, it was again frozen, and in mid 1989 it was again indexed monthly. In early 1990 , it was $45 \%$ lower than in early 1989; in late 1991, it was again monthly indexed. In 1993, adjustments were bi-monthly and then monthly. In early 1994, adjustments were daily, and in mid July, the minimum wage was decreased by $40 \%$. In mid 1995 it was increased by $42 \%$, and since then it has been annually adjusted.

\subsection{Wages and Employment}

The data used is PME (Monthly Employment Survey) for six metropolitan regions between 1982 and 2000, available from IBGE (Instituto Brasileiro de Geografia e Estatistica). This data has a similar design to the US CPS (Current Population Survey). The regional deflator, IPC (Consumers Price Index) is also available from IBGE.

Graphs 2.a to 2.c plot the $90^{\text {th }}$ to $10^{\text {th }}, 90^{\text {th }}$ to $50^{\text {th }}$ and $50^{\text {th }}$ to $10^{\text {th }}$ percentile ratios of the log real earnings distribution for both the formal and informal sectors over time. The trend is negative for all ratios. In the informal sector, the trend is strong and significant in all ratios, stronger in the $90^{\text {th }}$ to $10^{\text {th }}$ and $50^{\text {th }}$ to $10^{\text {th }}$, suggesting that most of the increase in inequality happened in the bottom half of the distribution. In contrast, in the formal sector the trend is not statistically significant in the $90^{\text {th }}$ to $10^{\text {th }}$ or $50^{\text {th }}$ to $10^{\text {th }}$ ratios, and is negative in the $90^{\text {th }}$ to $50^{\text {th }}$, suggesting that inequality did not increase by as much in the bottom half of the distribution in the formal sector. This, coupled with the negative trend in the log real minimum wage (see Graph 1.b) and the fact that the minimum wage is more binding in the informal sector (see Graphs 3.a and 3.b), suggests that the minimum wage might have contributed to cause more inequality in the informal than in the formal sector in the sample period. This is confirmed by the correlation between the log real minimum wage and the $50^{\text {th }}$ to $10^{\text {th }}$ ratio in the formal and informal sectors (on the top of each graph) of -0.53 and 0.70 .

Graphs 3.a and 3.b show the log real earnings distribution for each month of 1992 for both sectors (the vertical line is the minimum wage). An effective minimum wage should produce spikes in the wage distribution, and that is what is observed in both sectors' distributions. This is reassuring of the importance of the minimum wage not only in the formal, but also in the informal sector. The spike is towards the bottom in the formal, whereas it is towards the centre of the wage distribution in the 
informal sector. On average over the sample period, spike is $10 \%$ in both sectors. ${ }^{2}$ This is large when compared to the 4\% spike in the US in 1993 (Dolado et al., 1996). The spike jumped from 2\% to 12\% in the national aggregate, and it jumped from $2 \%$ to $14 \%(0.3 \%$ to $12 \%)$ in the formal (informal) sector in response to the minimum wage increase in September of 1991, immediately after the real minimum wage reached its lowest level ever. This suggests large variation in both sectors.

Graphs 4.a to 4.c show three employment variables for both the formal and informal sectors over time: log total average hours worked in the working population, log average hours worked for those working and log employment rate. All three variables show a negative trend over time for the formal, but not for the informal sector. As a result of the 1988 Constitutional shortening of the length of the workweek and workday (see Section 2.1), the three variables show clear changes in their trend after that, in particular in the informal sector. The plots of the three employment variables, together with that of the real minimum wage (see Graph 1.b), do not offer much support for a negative effect of the minimum wage on employment in the formal sector, but might offer some support for negative effect in the informal sector. The correlation between the minimum wage (on the top of each graph) and total hours worked is strong in both sectors, positive in the formal sector (0.59) and negative in the informal sector (-0.58). The correlation between the minimum wage and the number of hours worked by those working is stronger in the informal (0.46) than in the formal $(0.12)$ sector. The correlation between the minimum wage and the employment rate is strong and positive $(0.57)$ for the formal sector and stronger and negative (-0.67) for the informal sector. This suggests that when the minimum wage is increased, the total number of hours worked increases in the formal and decreases in the informal sector, the latter mainly through a decrease in the employment rate.

\section{Wages Effects}

Assuming no sorting by wages into the formal and informal sectors (random assignment); and full compliance with the minimum wage legislation in both sectors; the formal and informal sector wage distributions would look the same and the effects of the minimum wage on wages would also be the same in the two sectors. Further assuming the same labour demand elasticity in both sectors, the effects of the minimum wage on employment would again be the same in the two sectors (see Section 4.2).

\footnotetext{
${ }^{2}$ Spike varies greatly over the sample period. In general, it is larger for poorer regions and in higher inflation periods, for example: it is as high as $25 \%$ in poorer regions, where the informal sector is larger; it was $14 \%(14 \%)$ in the formal (informal) sector in 1992, a year of high inflation, and 12\% (5\%) in 1984 and 8\% (13\%) in 1996, years of low inflation. Spike has become larger in the informal sector as worsening macroeconomic conditions in the late 90 s enlarged that sector.
} 
If any of these assumptions is relaxed, the effect of the minimum wage could differ across sectors. First, if individuals with particular characteristics sort themselves into one or another sector, as not all such characteristics are observed, correlation between the observables and unobservables could contaminate the minimum wage coefficients with endogeneity bias. Even though the underlying coefficients could still be the same, the null could be incorrectly rejected because of the bias. Second, even if there is no sorting, compliance with the legislation might only take place in the formal sector. Third, even in the presence of no sorting and full compliance in both sectors, the employment response to the minimum wage might differ if the labour demand elasticities are different across sectors (see Section 4.2).

Graph 3, discussed in Section 2.2, show the wage distributions look different in both sectors. The initial wage is lower and as a consequence the minimum wage cuts deeper into the informal sector wage distribution. The distinctive feature is that spike is located towards the centre of the distribution in the informal sector, while it is at the bottom of the distribution in the formal sector. However, the spike is about the same magnitude in both sectors in the sample period. This suggests that the same effective pay (one minimum wage) is paid in both sectors. Non-compliance is observed as below minimum wage workers and on other aspects of the labour contract, such as social security taxes, paid holidays, health insurance, etc. (Amadeo et al., 1995; Amadeo and Camargo, 1997; Cox-Edwards, 1997). Workers and firms are better off with that deal; workers take the same pay home (which they could not get in the formal sector) and firms pay less (overhead costs are around $100 \%$ of the wage in Brazil). This way, the informal sector offers a way of avoiding the inefficiencies of labour market regulation (Maloney, 1999; Soto, 1989; Loayza, 1997). The presence of a spike in both sectors has been documented for Brazil and other Latin America countries (Maloney and Mendez, 2003; Gonzaga et al., 1999); the presence of a spike in the uncovered sector has also been documented for the US (Card and Krueger, 1995; Brown, 1999).

Not only the wage distributions in both sectors look different, but they are also affected differently by the minimum wage. Graphs 5.a and 5.b show the non-parametric Kernel estimation of the log real earnings distribution for each month of 1992 before and after each minimum wage increase. Graphs titled April-May, August-September and December-January show the change in the shape of the distribution (the right-most distribution), confirming the expected compression effect (see Section 1). The compression effect is strong in both sectors, but it is at the bottom of the distribution in the formal sector and towards the centre of the distribution in the informal sector, because of the position of the spike in each sector's distribution. This is in line with the evidence in Graph 2 that suggests that the 
minimum wage is more strongly correlated with lower percentiles of the formal sector and higher percentiles of the informal sector (see Section 2.1). This is also in line with previous empirical evidence for Brazil and for other developing countries (Fajnzylber, 2001; Gonzaga et al., 1999; Carneiro, 2000; Edwards and Cox-Edwards, 2002; Maloney and Mendez, 2003). Nonetheless, shifts in the distribution might be due to changes in variables other than the minimum wage. Thus, regression models are estimated for each sector to control for such variables (see Section 3.1).

The above pieces of evidence, taken together, suggest that the effect of the minimum wage is different across sectors and estimating the aggregate effect does not suffice. It is important to investigate the formal and informal sectors effect underlying the aggregate effect in Brazil - especially because the informal sector is large and overpopulated by minimum wage workers. Estimating the wage effects on the informal sector, where most of the poorer workers are, will give an indication of the effectiveness of the legislation where it matters most.

\subsection{Model Specification}

Following Lemos (2004), a simple empirical model of wages as a function of the minimum wage, grounded on the standard neoclassical theory, is:

$\Delta \log$ rwage $_{r t}=\alpha^{w}+\beta^{w} \Delta \log r M W_{r t}+\gamma^{w}$ inf lation $_{r t-1}+\delta^{w}$ surate $_{r t}+\lambda^{w}$ controls $_{r t}+f_{r}^{w}+f_{t}^{w}+u_{r t}^{w}$

where rwage $_{i r t}$ is $\log$ real hourly average real wages in region $r$ and month $t, r=1, \ldots, 6$, and $t=1, \ldots, 214 ; r M W_{r t}$ is $\log$ hourly real minimum wage ${ }^{3}$ inf lation $_{r t-1}$ is past inflation; urate $e_{r t}$ is unemployment rate; $f_{r}^{w}$ and $f_{t}^{w}$ are region and time fixed effects modeled by region and time dummies; $u_{i r t}^{w}$ is the error term; and controls $_{r t}$ are variables that control for region specific demographics correlated with the minimum wage, i.e. the proportion of workers in the population who are: young, younger than 10 years old, women, illiterates, retired, students, in urban areas, in the public sector, in the building construction industry sector, in the metallurgic industry sector, basic education degree holders, high school degree holders, and the proportion of workers with a second job. ${ }^{4}$ The

\footnotetext{
${ }^{3}$ The hourly minimum wage rate is obtained by dividing the monthly minimum wage by $44 \times 4.3$ after, and $48 \times 4.3$ until September of 1988, when the New Constitution shortened the working week. The hourly wage rate is obtained by dividing monthly earnings by 4.3 times the number of hours worked weekly.

${ }^{4}$ Typically, employment equations in the literature have been interpreted as demand equations, even though many include supply side variables (Card and Krueger, 1995). The debate is about whether a reduced form or a demand equation is estimated (Brown, 1999). Particularly debatable is the inclusion of a variable measuring enrolment rates in school (Card and
} 
regional dummies model region specific trends because regions are expected to differ not only in their business cycles but also in the pace of the cycle. The models were sample size weighted to account for the relative importance of each region (and heteroskedasticity arising from aggregation) and Whitecorrected.

This model can be estimated not only using average wages, but also the $5^{\text {th }}, 10^{\text {th }}, 15^{\text {th }}, 20^{\text {th }}, 25^{\text {th }}$, $30^{\text {th }}, 35^{\text {th }}, 40^{\text {th }}, 45^{\text {th }}, 50^{\text {th }}, 90^{\text {th }}$ and $95^{\text {th }}$ percentiles of the wage distribution. This makes it possible to estimate the effect of the minimum wage throughout the wage distribution (Dickens et al., 1999).

The typical minimum wage variables used in the literature are the real minimum wage and the "Kaitz index" (Kaitz, 1970), defined as the ratio of the minimum wage to average wage adjusted for coverage of the legislation. Two other minimum wage variables are the "fraction affected", defined as the proportion of workers earning a wage between the old and the new minimum wage (Card, 1992) and the "spike" in the wage distribution generated by the minimum wage (see Section 2.2), defined as the proportion of workers earning one minimum wage (Dolado et al., 1996) (plus or minus 0.02\%, to account for rounding approximations).

Although the Kaitz index (real minimum wage) varies across regions and over time, the variation in the average wages (deflator) is what drives the variation in the ratio, because the nominal minimum wage in Brazil is national (see Section 2.1). As a result, the effect of the inverse of the average wages (deflator) on wages is what would ultimately be estimated (Welch and Cunningham, 1978; Freeman, 1982). Brown (1999) compares the "degree of impact" measures (e.g. fraction affected) and the "relative minimum wage" variable (e.g. Kaitz index) and concludes that the former are conceptually cleaner because they measure the effect of the minimum wage at the point that really matters. Nonetheless, fraction is constant at zero for as long as the minimum wage is constant and does not capture the erosion of the minimum wage in relation to other wages, unlike spike. Spike is not only a measure of this erosion, but also a measure of those workers whose wages went up and thus is a measure of extra wage and employment costs. Its correlation with the log hourly real minimum wage and the Kaitz index in the sample period is 0.61 and 0.67 respectively. ${ }^{5}$

Krueger, 1995; Neumark and Wascher, 1992 and 1996), which was not included here because of the unresolved debate (Williams, 1993; Baker et al., 1999).

${ }^{5}$ Unlike in Section 2, spike is here defined using real hourly wages rather than real earnings. The correlation between the monthly and the hourly definitions of spike is high and the estimation results in Sections 3 and 4 are robust to either definition, suggesting negligible measurement errors. The hourly definition ensures that the results are consistent with theory and comparable with the existing empirical literature (most countries have hourly minimum wage). It also plays a crucial role when defining the employment decomposition in Section 4.1. 
Thus, to ensure identification, the log hourly real minimum wage in Equation (1) is replaced by the spike (Lemos, 2004). Even though spike has variation across regions and over time, modeling time effects with interactions of (12) month and (16) year dummies would eliminate all the variation in the model. That is because the variation in the minimum wage (and associated variation in spike) is not independent of the variation in the time dummies since the minimum wage is systematically increased on a particular month (mostly in May). To preserve the relevant variation, only the interaction of (11) month and (16) year dummies, excluding the May interaction but including a seasonal-month May dummy, are included to model time fixed effects. The May seasonal dummy ensures that spike explains the variation in wages due to minimum wage variation over and above the variation explained by seasonal macro shocks in May.

\subsection{Results}

Equation (1) is estimated separately for each sector. Table 1 shows estimates calibrated to express the effect of a $10 \%$ minimum wage increase. While the estimates are larger at the bottom of the distribution in the formal sector, they are larger and significant at higher percentiles in the informal sector. A $10 \%$ increase in the nominal minimum wage increases spike by 0.3 percentage points and is associated with an increase in the wages of those in the $10^{\text {th }}\left(20^{\text {th }}\right)$ percentile of $0.49 \%(0.05 \%)$ in the formal and of $0.52 \%(0.43 \%)$ in the informal sector. Lemos (2004) and Card and Krueger (1995) interpret their fraction estimates in a similar manner. ${ }^{6}$ Table 1 also shows estimates for percentile ratios and standard deviation regressions, whereby percentile ratios and the standard deviation of the $\log$ real hourly wage distribution replace log real hourly average wages in Equation (1). A 10\% increase in the nominal minimum wage is associated with a decrease in the $90^{\text {th }}-10^{\text {th }}$ percentile gap of $0.89 \%(0.50 \%)$, decomposed into an increase (decrease) in the $90^{\text {th }}-50^{\text {th }}$ gap of $0.03 \%(0.22 \%)$ and in the $50^{\text {th }}-10^{\text {th }}$ gap of $0.92 \%(0.28 \%)$ in the formal (informal) sector.

This evidence shows that the minimum wage compresses the wage distribution of both sectors. The compression effect extends higher in the informal sector wage distribution, but it is stronger at the

\footnotetext{
${ }^{6}$ The 0.3 calibration factor is the coefficient of the nominal minimum wage on a regression of the difference of spike on the difference of the $\log$ of the nominal minimum wage and the other regressors in Equation (1). Because the nominal minimum wage does not vary across regions (see Section 2.1), log Kaitz index and its variations (where the median and the $25^{\text {th }}$ percentile replace the average wages) were also used, producing remarkably robust results. This can be intuitively understood by comparing it with a deterministic model where $y=a_{1}+b_{1} x, y=a_{2}+b_{2} z, z=a_{3}+b_{3} x$ and $b_{1}=b_{2} b_{3}$, $\forall b_{1}, b_{2}, b_{3} \neq 0$ (Lemos, 2004).
} 
bottom of the formal sector wage distribution. This is in line with the evidence discussed in Section 3 that shows that the minimum wage cuts deeper into the informal sector wage distribution (see Graph 3 ) and as a consequence the compression effect is at the bottom of the distribution in the formal sector and towards the centre of the distribution in the informal sector (see Graph 5). This suggests that the minimum wage redistributes in favour of the poorer in both sectors, but that it redistributes in favour of those in the very bottom of the distribution in the formal sector, while it redistributes more widely in favour of those in the bottom half of the distribution in the informal sector. Because the initial level of wages is much lower in the informal sector (the actual percentile where the minimum wage is changes over time, but while it is somewhere between the 5th and 10th percentile in the formal, it is somewhere between the 15th and the 30th percentile in the informal sector wage distribution) this benefits a large proportion of poor workers. Put differently, the minimum wage is effective in the informal sector both above and below the minimum wage (Reis, 1989; Neri, 1997; Gonzaga et al., 1999; Carneiro, 2000).

The above evidence is in line with previous empirical evidence for Brazil and for other developing countries. Fajnzylber (2001) found significant wage effects throughout the wage distribution for both formal and informal sectors; Neumark et al. (2003) documented wage effects at the bottom of the formal sector wage distribution; Corseuil and Morgado (2001) and Corseuil and Carneiro (2001) found supporting evidence of compression effect using both full and formal sector sample. Other studies also reported evidence supportive of spillovers for both sectors in Brazil by estimating average and median wage models across sectors (Velloso, 1988; Neri, 1997; Foguel, 1997; Gonzaga et al. 1999). Maloney and Mendez (2003) also report evidence supporting the compression effect in various Latin American countries, whereas Gindling and Terrell (1995) report a decrease in wage inequality in the covered sector (read formal sector for that country) but not in the self-employed sector (read informal sector for that country) for Costa Rica.

\section{Employment Effects}

As discussed in Section 3, if the wage distribution and the labour demand elasticity are the same across sectors, the effect of the minimum wage on employment would also be the same in both sectors. On the one hand, unfortunately, there is no evidence on the elasticity of the labour demand across sectors in Brazil. On the other hand, the evidence in Section 3 shows that not only the wage distributions across sectors look different, but also that they are affected differently by the minimum wage. The presence of a spike, spillover effects, and the associated compression effect in both sectors, 
suggest that employment decreases in both sectors. However, the compression effect differs substantially in the two sectors, suggesting that the employment effect might also differ.

Graph 4, discussed in Section 2.2, shows the plots and correlations of the three employment variables and the minimum wage for each sector. This does not offer much support for a negative effect of the minimum wage on employment in the formal, but might offer some support for a negative effect in the informal sector. The correlations between the minimum wage and the employment variables suggest that when the minimum wage is increased, the total number of hours worked increases in the formal and decreases in the informal sector, the latter mainly through a decrease in the employment rate. However, such raw correlations need to be proved robust when the effect of other variables (demand and supply shocks) on employment is controlled for. Thus, regression models are estimated for each sector control for such variables (see Section 4.1).

Therefore, it is important to estimate the employment effect across sectors to confirm whether it differs in both sectors. In case it differs, it might not suffice to estimate the aggregate employment effect in Brazil, and the underlying formal and informal sectors estimates need to be uncovered. Estimating the employment effect in the informal sector, where most of the poorer workers are, will give an indication of whether the minimum wage legislation disemploys those who could benefit most from the legislation.

\subsection{Model Specification}

Following Lemos (2004), a simple empirical model of employment as a function of the minimum wage, grounded on the standard neoclassical theory, is:

$$
\log \text { employment }_{r t}=\alpha^{e}+\beta^{e} \log r M W_{r t}+\gamma^{e} \text { inf } \text { lation }_{r t-1}+\lambda^{e} \text { controls }_{r t}+f_{r t}^{e}+f_{r t}^{e}+u_{r t}^{e}
$$

where employment $t_{r t}$ is taken in turn to mean average hours in the population $(\bar{T})$, average hours for those working $(\bar{H})$ and the employment rate $(E)$; and the other regressors are as in Section 3.1. Allowing dynamics, to account for lagged responses in employment (Hamermesh, 1995), the new equation is: ${ }^{7}$

$\log$ employment $_{r t}=\alpha^{e}+\beta^{e} \log r M W_{r t}+\gamma^{e} \inf$ lation $_{r t-1}+\lambda^{e}$ controls $_{r t}+\sum_{l=1}^{24} \rho_{l}^{e} \log$ employment $_{r t-1}+f_{r}^{e}+f_{t}^{e}+u_{r t}^{e}$ 
Estimating Equations (2) and (2') separately using each of the three employment variables $(\bar{T}, \bar{H}$ and $E$ ) in turn as dependent variables, assuming a log-log form, and using the same set of regressors in each one of the three equations, the estimate of the real minimum wage in the $\bar{T}$ equation equals the sum of the estimates of the real minimum wage in the $\bar{H}$ and $E$ equations, i.e. $\beta_{T}^{e}=\beta_{H}^{e}+\beta_{E}^{e}{ }^{8}{ }$ This makes it possible to decompose the total effect of a minimum wage increase on employment into hours effect and jobs effect (Lemos, 2004).

As in Section 3.1, to ensure identification, the log hourly real minimum wage in Equations (2) and $\left(2^{\prime}\right)$ is replaced by the spike. The models were again White-corrected and sample size weighted. By modelling regional and time fixed effects and including controls and dynamics, the errors are no longer expected to be serially correlated over time. ${ }^{9}$

\subsection{Results}

Equations (2) and (2') are estimated separatedy for each sector. Table 2 shows estimates calibrated to express the effect of a $10 \%$ minimum wage increase (see Section 3.2). Estimates for the dynamic model in column 2 shows that a $10 \%$ increase in the nominal minimum wage (increases spike by 0.3 percentage points and) is associated with an increase in total employment of $0.06 \%(0.04 \%)$ in the formal (informal) sector, decomposed into $0.10 \%(0.21 \%)$ increase in the number of hours worked and $0.04 \%(0.17 \%)$ decrease in the number of jobs. After two years of adjustments, total employment increases by $0.03 \%(0.02 \%)$ and jobs decrease by $0.04 \%(0.09 \%)$. For both sectors, the total and hours effect estimates were smaller before, but the job effect estimates were larger after including dynamics. The estimates are in the main more robust in the dynamic models.

The jobs effect is negative in both sectors, stronger and more robust in the informal sector both in the short and in the long run. The null hypothesis of identical job effects across sectors was rejected at the usual significance levels. It appears that either one or more of the assumptions discussed in Section 3 does not hold and thus the jobs effect differs in the two sectors. Endogeneity might be enough to

\footnotetext{
${ }^{7}$ Employment is reported to be AR(2) using annual data (Layard et al., 1991), which is equivalent to 24 lags on monthly data. The results were robust to including 12 lags only, but that was thought to prematurely censor the adjustment process because lags beyond 12 were still significant.

${ }^{8}$ Because of dynamics, the set of regressors is not the same in all three equations and the OLS additivity property does not hold exact. To preserve the decomposition, lagged $\bar{T}$, which embodies the variation of $\bar{H}$ and $E$, was used in all three equations without affecting the robustness of the estimates (Lemos, 2004).
} 
contaminate the results as to reject the null; non-compliance in the informal sector, even on aspects of the labour contract other than the take-home pay, might also be enough to make the null to be rejected; and finally, different labour demand elasticities might drive the null to be rejected. As a result, the employment response to minimum wage increases is different in the formal and informal sectors.

Table 2 also shows estimates for unemployment rate regressions, whereby log unemployment rate replaces log employment rate in Equations (2) and (2'). Estimates for the dynamic model in column 2 shows that a $10 \%$ increase in the nominal minimum wage (increases spike by 0.3 percentage points and) is associated with an increase in unemployment of $0.21 \%$ in the short and $0.13 \%$ in the long run.

These results are not surprising and are rather reassuring of other features of the data. Negative employment rate effects (jobs effects) in both sectors and positive unemployment rate effects are consistent with the presence of a spike, spillover effects, and the associated compression effect in both sectors reported in Section 3. Furthermore, these results are in line with previous empirical evidence for Brazil and for other developing countries. Fajnzylber (2001) and Foguel (1997) found evidence supporting a negative employment effect for both formal and informal sectors; although Carneiro (2000) found evidence supporting a negative effect in the formal and a positive effect in the informal sector employment. Maloney and Mendez (2003) found evidence supporting a negative employment effect on both the formal and the self-employment sectors in Colombia. El-Hamidi and Terrell (2001) found evidence supporting an increase in the covered and no effect in the uncovered sector employment. In contrast, Gindling and Terrell (1995) were unable to find evidence of employment effect in the formal sector in Costa Rica, but found a positive employment effect in the informal sector.

\subsection{Robustness Checks}

Equations (2) and (2') were also estimated using first-differences as an alternative data filter. Time and regional dummies, past inflation and the constant were included after differencing. The constant is the base dummy (not a trend from the model in levels), and the regional dummies model region specific trends (see Section 3.1). The difference of spike replaced the log of the difference of hourly real minimum wage. The models were again White-corrected and sample size weighted, and the errors were again assumed to be serially uncorrelated over time.

\footnotetext{
${ }^{9}$ The results were robust to SUR estimation. GMM a la Arellando and Bond (1991) is not an option because T>N. Lemos (2003) shows that any endogeneity coming from the simultaneous determination of spike and employment is not too severe and that OLS estimates are robust to GMM estimates using a number of instruments for spike.
} 
Table 3 shows estimates calibrated to express the effect of a $10 \%$ minimum wage increase (see Section 3.2). Estimates for the dynamic model in column 2 shows that a $10 \%$ increase in the nominal minimum wage (increases spike by 0.3 percentage points and) is associated with an increase in total employment of $0.06 \%(0.16 \%)$ in the formal (informal) sector, decomposed into $0.08 \%(0.06 \%)$ increase in the number of hours worked and $0.01 \%(0.10 \%)$ decrease (increase) in the number of jobs. After two years of adjustments, total employment decreases by $0.11 \%(0.19 \%)$ and jobs decrease (increase) by $0.02 \%(0.43 \%)$.

The jobs effect is smaller and still negative in the formal, but now positive in the informal sector. However, none of the jobs effects estimates is statistically significant, and thus the evidence is taken to mean that an increase in the minimum wage does not affect jobs. The null hypothesis of identical job effects across sectors could not be rejected at the usual significance levels (this might have been driven by not enough variability in the data to reject the null, although that was not the case in Section 4.2).

Table 3 also shows estimates for unemployment rate regressions. Estimates for the dynamic model in column 2 shows that a $10 \%$ increase in the nominal minimum wage (increases spike by 0.3 percentage points and) is associated with a decrease in unemployment of $0.30 \%$ in the short and $0.07 \%$ in the long run. Nonetheless, these estimates are again not statistically significant, and the evidence is taken to mean that an increase in the minimum wage does not affect the unemployment rate.

The evidence of non-significant employment rate effects (jobs effects) in both sectors and nonsignificant unemployment rate effects is not sufficiently strong to change the previous conclusions in Section 4.2 .

\section{Empirical Evidence and Theory Predictions}

Although the above evidence on wages (see Section 3) and employment effects (see Section 4) is in line with previous empirical evidence for Brazil and for other developing countries, it is not in line with theory. The standard Welch-Gramlich-Mincer Two Sector Model major's prediction, following a minimum wage increase, is that the uncovered sector wages fall as a result of covered sector displaced workers moving into uncovered sector employment. It follows that, in the uncovered sector, a spike should not be observed in the wage distribution and the labour demand curve should not be downwards sloping (Welch, 1976; Gramlich, 1976; Mincer, 1976). These predictions do not hold for Brazil. A sizeable spike, as well as substantial spillover effects and strong compression effects, are observed in both sectors. Furthermore, employment rate effects (job effects) are negative in both sectors and 
unemployment rate effects are positive. This suggests a downwards sloping labour demand curve in both sectors, challenging the standard Two Sectors Model as inadequate to explain the effect of the minimum wage on the formal and informal sectors in Brazil and in Latin America more generally.

The predictions of the Two Sectors Model follow from the assumption of non-coverage. The Brazilian informal market suffers from non-compliance, not non-coverage. That is the key difference between the US and the Brazilian literature on uncovered and informal sector minimum wage effects. Informal sector wages and employment need not respond to an increase in the minimum wage in the same way that uncovered sector wages and employment respond. Maloney and Mendez (2003) question the validity of the standard Two Sector Model to explain the formal and informal sector in Latin America. Barros et al. (1997) discuss both the Cloistering Effect and Lighthouse Effect and conclude that the second dominates the first in Brazil. The first one predicts negative effects on wages below the minimum wage, within the standard Welch-Gramlich-Mincer Two Sector Model, whereas the second one predicts positive effects on wages, even on those below the minimum wage (Souza dn Baltar, 1979 and 1980). Mincer (1976) notes that the prediction of falling uncovered sector wages is not robust to alternative assumptions on sectoral choice and unemployment. Edwards and Lustig (1997) argue that the Harris-Todaro prediction of fall in uncovered sector wages depends on various elasticities, in particular on the labor demand elasticity (Haris and Todaro, 1970). Card and Krueger (1995) show that the uncovered sector wages rise (and employment falls) if the covered sector labour demand curve is relatively inelastic. The labour demand curve for the industry (mainly formal sector firms) in Brazil is fairly inelastic (Barros et al., 2001).

\section{Policy Implications}

The evidence here suggests that the poorest are not out of the reach of the legislation, despite of being over-represented in the informal sector, where the legislation is not complied with. The minimum wage is effective throughout the bottom half of the distribution. Spillover effects are substantial and robust at the lowest percentiles, benefiting even those below the minimum wage.

Although the effect on wages is sizeable, the employment effects of the minimum wage are small for Brazil when compared to the $-1 \%$ in the international literature (Brown, 1999). The employment rate effect (job effects) is at the most $-0.04 \%$ in the formal and $-0.17 \%$ in the informal sector.

Camargo (1989) and Carneiro and Henley (2001) argue that a policy such as this might be more effective to reduce poverty than policies that attempt to incorporate informal sector workers into the 
formal sector, which might generate higher unemployment. Furthermore, the informal sector, as a way of avoiding the inefficiencies of labour market regulation (Soto, 1989; Loayza, 1997; Maloney, 1999), is large and growing in Brazil as a result of successive stabilization plans (Fox and Morley, 1989). The excess of regulations increase non-compliance, and non-compliance increases the de facto size of the informal sector (Ashenfelter and Smith, 1979). Neri (1997) argues that minimum wage increases are more likely to informalize than to destroy jobs. In a developing country, with very little social security, people cannot afford to stay out of work and will move into lower paid informal sector jobs (Macedo, 1981; Amadeo et al., 1995; Carneiro and Henley, 1998). McIntyre (2002) reported evidence confirming that the minimum wage increases the size of the informal sector in Brazil.

\section{Conclusion}

There is very little evidence on the effects of the minimum wage in developing countries and in particular on these effects on the formal and informal sectors of such countries. The informal sector is not only large and overpopulated by minimum wage workers in Brazil, but it is also where most of the poor workers are. Extending the understanding of minimum wage effects both in developing countries and in particular in the informal sector is crucial if the minimum wage is to be used as a policy to help poor people in poor countries.

This paper estimates wage and employment effects in both the formal and informal sectors for a key developing country, namely Brazil.

The minimum wage was found to compress the wage distribution of both sectors. The compression effect extends higher in the informal sector wage distribution, but it is stronger at the bottom of the formal sector distribution. This suggests that the minimum wage redistributes in favour of the poorer in both sectors, but that it redistributes in favour of those in the very bottom of the distribution in the formal sector, while it redistributes more widely in favour of those in the half bottom half of the distribution in the informal sector.

Consistent with the presence of a spike, spillover effects, and the associated compression effect in both sectors, employment was found to decrease in both sectors. Negative employment rate effects (jobs effects) were found to be negative in both sectors - stronger in the informal sector - and aggregate unemployment rate effects was found to be positive.

The compression effect together with the disemployment effect of the minimum wage in the informal sector in Brazil is the novelty here. This suggests a downwards sloping labour demand curve 
in both sectors, challenging the standard Two Sectors Model as inadequate to explain the effect of the minimum wage on the formal and informal sectors in Brazil and in Latin America more generally.

Most importantly, the novelty here is that the poorest are not out of the reach of the legislation. The findings here have important policy implications because they entail that the minimum wage is effective not only in the formal, but also in the informal sector, where legislation is not complied with. Furthermore, the minimum wage affects the wage of those above and even of those below the minimum wage in the informal sector, where the poorest workers are.

\section{References}

AMADEO, E., J. M. CAMARGO, and G. GONZAGA (1995): "Salario Minimo E Informalidade," Economia Capital e Trabalho, 3, 2 -4.

AMADEO, E., and J. M. CAMARGO (1997): "Brazil: Regulation and Flexibility in the Labour Market," in Labour Markets in Latin America, ed. by S. Edwards, and N. C. Lustig. Washington: Brookings Institution Press, 201-234.

ANGEL-URDINOLA, D. F. (2002): "Employment Effects of the Minimum Wage Can Affect Wage Inequality: The Case of Colombia," Unpublished Paper.

ARELLANO, M., and S. BOND (1991): "Some Tests of Specification for Panel Data: Monte Carlo Evidence and an Application to Employment Equations," Review of Economic Studies, 58, 277-297.

ASHENFELTER, O., and D. CARD (1981): "Using Longitudinal Data to Estimate the Employment Effects of the Minimum Wage," London School of Economics Discussion Paper, 98.

BAKER, M., D. BENJAMIN, and S. STANGER (1999): "The Highs and Lows of the Minimum Wage Effect: A Time-Series CrossSection Study of the Canadian Law," Journal of Labor Economics, 17, 318-350.

BARROS, R. P. D., M. FOGUEL, and R. MENDONCA (1997): "Salario Minimo I: O Nivel Do Salario Minimo No Brasil," Anais do XIX Encontro Brasileiro de Econometria, 383-402.

BARROS, A., and S. LEMOS (1998): "O Salario Minimo E O Salario Medio Na Economia Brasileira," Anais do XXVI Encontro Nacional de Economia, 1181-1198.

BARRoS, R. P., C. H. CORSEUIL, and G. GONZAGA (2001): "A Evolucao Da Demanda Por Trabalho Na Industria Brasileira: Evidencias De Dados Por Estabelecimento--1985/97," Pesquisa e Planejamento Economico, 31, 187-211.

BELL, L. A. (1997): "The Impact of Minimum Wages in Mexico and Colombia," Journal of Labor Economics, 15, S102-S135.

BROWN, C. (1999): "Minimum Wages, Employment, and the Distribution of Income," in Handbook of Labor Economics, ed. by O. Ashenfelter, and D. Card. Amsterdam; New York and Oxford: Elsevier Science, North-Holland, 2101-2163.

BURKHAUSER, R. V., K. A. COUCH, and D. C. WITTENBURG (2000): "A Reassessment of the New Economics of the Minimum Wage Literature with Monthly Data from the Current Population Survey," Journal of Labor Economics, 18, 653-680.

CAMARgO, J. M. (1989): "Informalizacao E Renda No Mercado De Trabalho," in Mercado De Trabalho E Distribuicao De Renda: Uma Coletanea, ed. by G. L. Sedlacek, and R. P. Barros. Rio de Janeiro: IPEA/INPES/RJ, 117-133.

CARD, D. (1992): "Do Minimum Wages Reduce Employment? A Case Study of California, 1987-89," Industrial and Labor Relations Review, 46, 38-54.

CARD, D. E., and A. B. KRUEGER (1995): Myth and Measurement: The New Economics of the Minimum Wage. Princeton: Princeton University Press.

— (2000): "Minimum Wages and Employment: A Case Study of the Fast-Food Industry in New Jersey and Pennsylvania: Reply," American Economic Review, 90, 1397-1420. 
CARNEIRO, F. (2000): "The Impact of Minimum Wages on Wages, Employment and Informality in Brazil," Unpublished Paper.

— (2002): "Uma Resenha Empirica Sobre Os Efeitos Do Salario Minimo No Mercado De Trabalho Brasileiro," Unpublished Paper.

CARNEIRO, F., and J. FARIA (1998): "O Salario Minimo E Os Outros Salarios No Brasil," Anais do XXVI Encontro Nacional de Economia, 1169-1180.

CARNEIRO, F., and A. HENLEY (2001): "Modelling Formal Versus Informal Employment and Earnings: Microeconometric Evidence for Brazil," Anais do XXIX Encontro Nacional de Economia.

CASTILlO FREEMAN, A. J., and R. B. FREEMAN (1992): "When the Minimum Wage Really Bites: The Effect of the U.S.-Level Minimum on Puerto Rico," in Immigration and the Work Force: Economic Consequences for the United States and Source Areas, ed. by G. J. Borjas, and R. B. Freeman. Chicago and London: University of Chicago Press, 177-211.

CORBO, V. (1981): "The Impact of Minimum Wages on Industrial Employment in Chile," in The Economics of Legal Minimum Wages, ed. by S. Rottenberg. Washington: American Enterprise Institute, 340-356.

CORSEUIL, C. H., and F. G. CARNEIRO (2001): "Os Impactos Do Salario Minimo Sobre Emprego E Salarios No Brasil: Evidencias a Partir De Dados Longitudinais E Series Temporais," Unpublished Paper.

CORSEUIL, C. H., and W. MORGADO (2001): "Salario Minimo, Distribuicao De Salarios E Emprego No Brasil," Unpublished Paper.

CORSEUIL, C. H., and L. SERVO (2002): "Salario Minimo E Bem Estar Social No Brasil: Uma Resenha Da Literatura," Unpublished Paper.

COX-EDWARDS, A. (1997): "Labour Market Regulation in Latin America: An Overview," in Labour Markets in Latin America, ed. by S. Edwards, and N. C. Lustig. Washington: Brookings Institution Press, 127-150.

COWAN, K., A. MICCO, A. MIZALA, C. PAGÉS, and P. ROMAGUERA. (2003): "Un Diagnóstico Del Desempleo En Chile," Washington: Inter-American Development.

CURRIE, J., and B. C. FALLICK (1996): "The Minimum Wage and the Employment of Youth: Evidence from the Nlsy," Journal of Human Resources, 31, 404-428.

DEERE, D., K. M. MURPHY, and F. WELCH (1995): "Employment and the 1990-1991 Minimum-Wage Hike," American Economic Review, 85, 232-237.

DEERE, D., K. MURPHY, and F. WELCH (1996): "Examining the Evidence on Minimum Wages and Employment," in The Effects of the Minimum Wage on Employment, ed. by M. Kosters. Washington: AEI Press, 26-54.

DICKENS, R., S. MACHIN, and A. MANNING (1999): "The Effects of Minimum Wages on Employment: Theory and Evidence from Britain," Journal of Labor Economics, 17, 1-22.

DOLADO, J., and ET AL. (1996): "The Economic Impact of Minimum Wages in Europe," Economic Policy: A European Forum, 23, 317-357.

EDWARDS, S., and A. COX-EDWARDS (2002): "Social Security Privatization Reform and Labor Markets: The Case of Chile," Economic Development and Cultural Change, 50, 465-489.

EDWARDS, S., and N. C. LUSTIG (1997): Labor Markets in Latin America. Washington: Brookings Institution Press.

EL-HAMIDI, F., and K. TERRELL (2001): "The Impact of Minimum Wages on Wage Inequality and Employment in the Formal and Informal Sector in Costa Rica," William Davidson Institute Working Paper, 479.

FAJNZYLBER, P. (2001): "Minimum Wage Effects Throughout the Wage Distribution: Evidence from Brazil's Formal and Informal Sectors," Anais do XXIX Encontro Nacional de Economia.

FELICIANO, Z. M. (1998): "Does the Minimum Wage Affect Employment in Mexico?," Eastern Economic Journal, 24, $165-180$.

Foguel, M. N. (1997): "Uma Analise Dos Efeitos Do Salario Minimo Sobre O Mercado De Trabalho No Brasil," Rio de Janeiro: Pontificia Universidade Catolica do Rio de Janeiro.

FOGUEL, M. N., C. H. CORSEUIL, R. P. D. BARROS, and P. G. LEITE (2000): "Uma Avaliacao Dos Impactos Do Salario Minimo Sobre O Nivel De Pobreza Metropolitana No Brasil," Unpublished Paper.

FOGUEL, M. N., L. RAMOS, and F. CARNEIRO (2001): "The Impacts of the Minimum Wage on the Labor Market, Poverty and Fiscal 
Budget in Brazil," Unpublished Paper.

FOX, M. L., and S. A. MORLEY (1991): "Who Paid the Bill? Adjustment in Brazil, 1980-95," World Bank Paper Series, 648.

FREEMAN, R. (1982): "Economic Determinants of Geographic and Individual Variation in the Labor Market Position of Young

Persons," in The Youth Labor Market Problems: Its Nature, Causes and Consequences, ed. by R. Freeman, and D. Wise, 115-148.

FREEMAN, R. B. (1994): "Minimum Wages--Again!," International Journal of Manpower, 15, 8-25.

— (1996): "The Minimum Wage as a Redistributive Tool," Economic Journal, 106, 639-649.

GINDLING, T. H., and K. TERRELL (1995): "The Nature of Minimum Wages and Their Effectiveness as a Wage Floor in Costa Rica, 1976-91," World Development, 23, 1439-1458.

— (2002): "The Effects of Minimum Wages on the Formal and Informal Sector: Evidence from Costa Rica," Unpublished Paper.

GONZAGA, G., M. NERI, and J. M. D. CAMARGO (1999): "Distribuiçao Regional Da Efetividade Do Salário Mínimo No Brasil," Nova Economia, 9, 9-38.

GRAMLICH, E. M. (1976): "Impact of Minimum Wages on Other Wages, Employment, and Family Incomes," Brookings Papers on Economic Activity, 2, 409-451.

GREGORY, P. (1981): "Legal Minimum Wages as an Instrument of Social Policy in Less Developed Countries, with Special Reference to Costa Rica," in The Economics of Legal Minimum Wages, ed. by S. Rottenberg. Washington: American Enterprise Institute, $377-$ 402 .

HAMERMESH, D. (1995): "What a Wonderful World This Would Be," Industrial and Labor Relations Review, 48, 835-838.

HARRIS, J. R., and M. P. TODARO (1970): "Migration, Unemployment \& Development: A Two-Sector Analysis," American Economic Review, 60, 126-142.

KAITZ, H. (1970): "Experience of the Past: The National Minimum, Youth Unemployment and Minimum Wages," US Bureau of Labor Statistics Bulletin, 1657, 30-54.

LAYARD, R., S. NICKELL, and R. JACKMAN (1991): Unemployment. UK: Oxford University Press.

LEMOS, S. (2003): "Political Variables as Instruments for the Minimum Wage", UCL Working Paper, 03-04.

- (2004): “Are Wage and Employment Effects Robust to Alternative Minimum Wage Variables?”, University of Leicester Discussion Paper, 04/04.

LOAYZA, N. (1997): "The Economics of the Informal Sector: A Simple Model and Some Empirical Evidence from Latin America," World Bank Policy Research Working Paper, 1727.

LORA, E., and M. L. HENAO (1997): "Colombia: The Evolution and Reform of the Labor Market," in Labour Markets in Latin America, ed. by S. Edwards, and N. C. Lustig. Washington: Brookings Institution Press, 261-291.

MACEDO, R. (1976): "Salario Minimo E Distribuicao Da Renda No Brasil," Estudos Economicos, 11, 43-56.

MACHIN, S., and A. MANNING (1994): "The Effects of Minimum Wages on Wage Dispersion and Employment: Evidence from the U.K. Wages Councils," Industrial and Labor Relations Review, 47, 319-329.

MACHIN, S., A. MANNING, and L. RAHMAN (2003): "Where the Minimum Wage Bites Hard: Introduction of Minimum Wages to a Low Wage Sector," Journal of The European Economic Association, Inaugural Issue, 154-180.

MALONEY, W., and J. MENDEZ (2003): "Minimum Wages in Latin America," Unpublished Paper.

MALONEY, W. F. (1999): "Does Informality Imply Segmentation in Urban Labor Markets? Evidence from Sectoral Transitions in Mexico," World Bank Economic Review, 13, 275-302.

MANNING, A. (1994): "Labour Markets with Company Wage Policies," London School of Economics Centre for Economic Performance Discussion Paper., 214.

MCINTYRE, F. (2002): "How Does the Minimum Wage Affect Market Informality in Brazil," Unpublished Paper.

MINCER, J. (1976): "Unemployment Effects of Minimum Wages," Journal of Political Economy, 84, S87-S104.

MONTENEGRO, C., and C. PAGÉS (2004): "Who Benefits from Labor Market Regulations? Chile 1960-1998," in Law and Employment: Lessons from Latin America and the Caribbean., ed. by J. Heckman, and C. Pagés. Cambridge, MA.: NBER and University of 
Chicago.

NERI, M. (1997): "A Efetividade Do Salario Minimo No Brasil: Pobreza, Efeito-Farol E Padroes Regionais," Unpublished Paper.

NEUMARK, D., W. CUNNINGHAM, and L. SIGA (2003): "The Distributional Effects of Minimum Wages in Brazil: 1996-2001," Unpublished Paper.

NEUMARK, D., and W. WASCHER (1992): "Employment Effects of Minimum and Subminimum Wages: Panel Data on State Minimum Wage Laws," Industrial and Labor Relations Review, 46, 55-81.

- (1996): "The Effects of Minimum Wages on Teenage Employment and Enrollment: Evidence from Matched Cps Surveys," in Research in Labor Economics, ed. by S. W. Polachek. London: JAI Press, 25-63.

NEUMARK, D., and W. WASCHER (2000): "Minimum Wages and Employment: A Case Study of the Fast-Food Industry in New Jersey and Pennsylvania: Comment," American Economic Review, 90, 1362-1396.

REIS, G. A. (1989): "Salario Minimo E Distribuicao Da Renda," in Perspectivas Da Economia Brasileira. Rio de Janeiro: IPEA/INPES, 371-391.

REYNOLDS, L., and P. GREGORY (1965): Wages, Productivity and Industrialization in Puerto Rico. US: Homewood, Ill Richard D. Irwin Inc.

ROtTEnberg, S. (1981): "Minimum Wages in Puerto Rico," in The Economics of Legal Minimum Wages, ed. by S. Rottenberg. Washington: American Enterprise Institute, 327-339.

SOARES, S. S. D. (2002): "O Impacto Distributivo Do Salario Minimo: A Distribuicao Individual Dos Rendimentos Do Trabalho," Unpublished Paper.

SOTO, H. D. (1989): The Other Path - the Invisible Revolution in the Third World. New York: Harper and Row Publishers.

SOUZA, P., and P. BALTAR (1979): "Salario Minimo E Taxa De Salarios No Brasil," Pesquisa e Planejamento Economico, 9, 629-660.

SOUZA, P., and P. BALTAR (1980): "Salario Minimo E Taxa De Salarios No Brasil - Replica," Pesquisa e Planejamento Economico, 10, $1045-1058$.

VELlOSO, R. (1988): "Salario Minimo E Taxa De Salarios: O Caso Brasileiro," Unpublished Paper.

VILLARREAL, D., and B. SAMANIEGO (1998): "Evaluation of the Impact of Minimum Wages on Mexican Economy," in Assessing the Impact of Statutory Minimum Wages in Developing Countries. Geneva: International Labour Office, 81-110.

WELCH, F. (1976): "Minimum Wage Legislation in the United States," in Evaluating the Labor Market Effects of Social Programs, ed. by O. Ashenfelter, and J. Blum. US: Princeton University Press.

WELCH, F. R., and J. CUNNINGHAM (1978): "Effects of Minimum Wages on the Level and Age Composition of Youth Employment," Review of Economics and Statistics, 60, 140-145.

WILLIAMS, N. (1993): "Regional Effects of the Minimum Wage on Teenage Employment," Applied Economics, 25, 1517-1528.

ZAVODNY, M. (2000): "The Effect of the Minimum Wage on Employment and Hours," Labour Economics, 7, 729-750. 

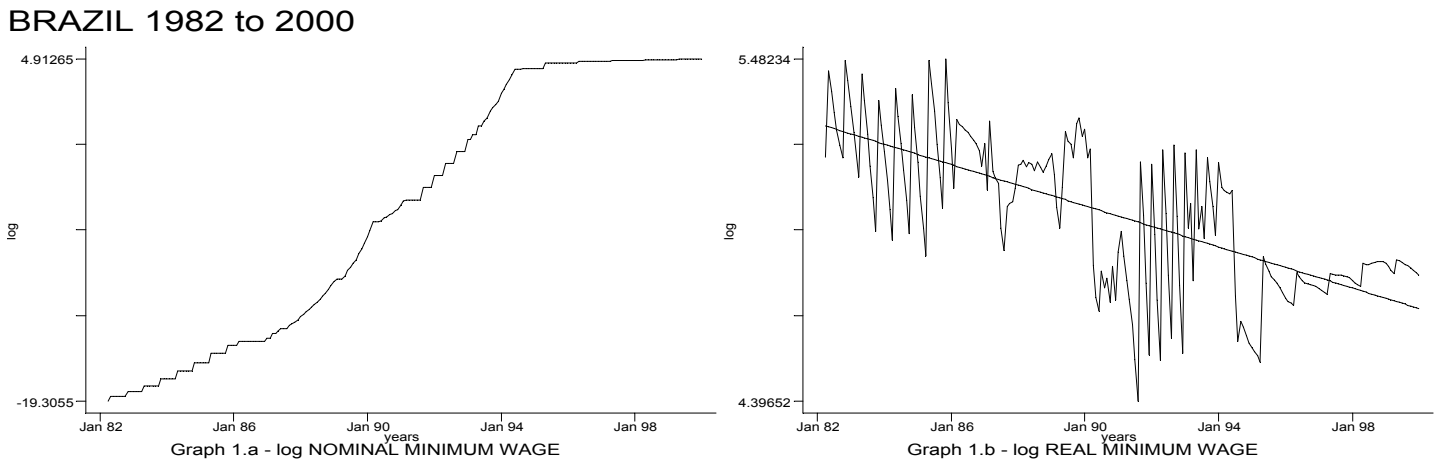

Graph 1 - MINIMUM WAGE

FORMAL AND INFORMAL SECTORS 1982 to $200 \mathrm{C}$
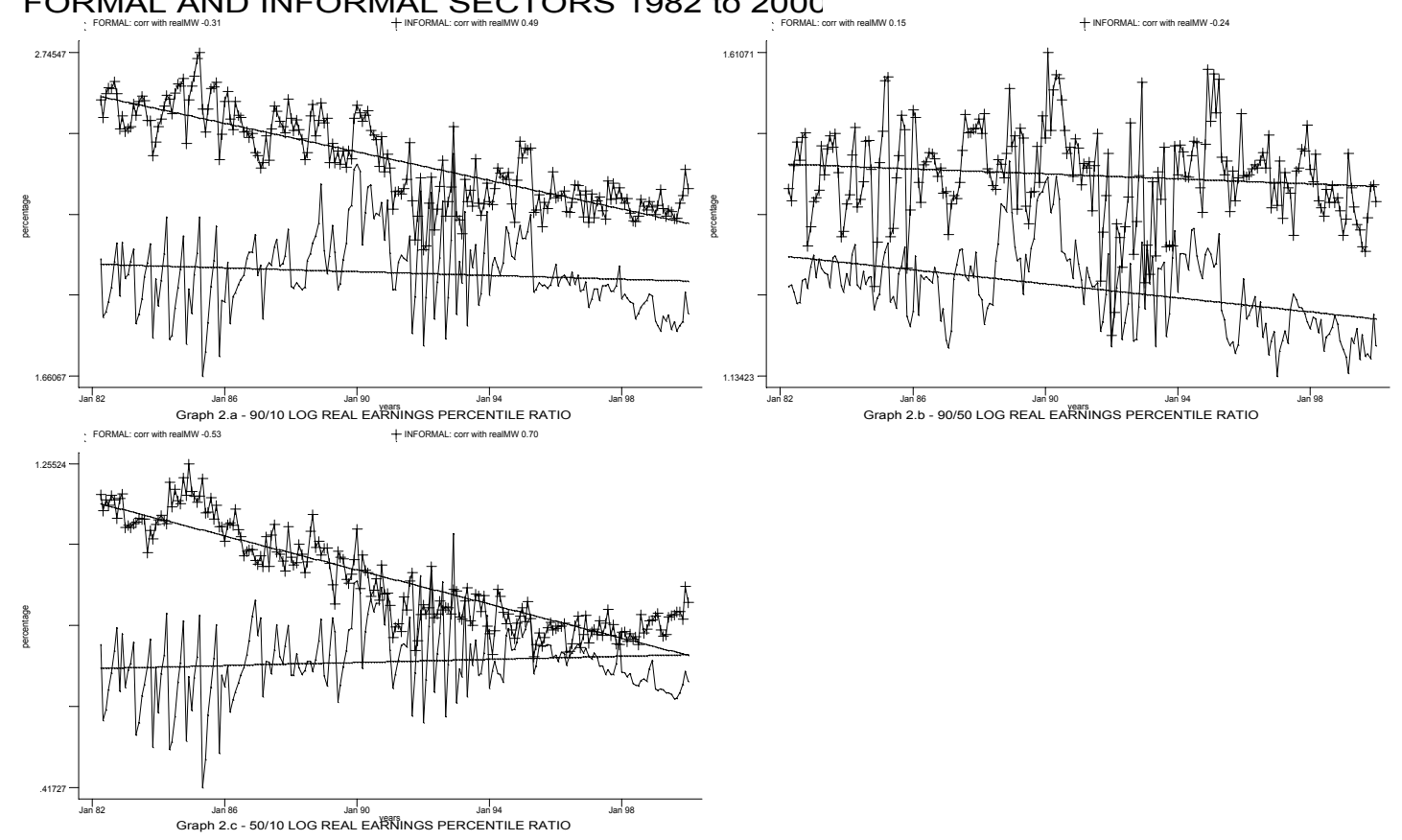

Graph 2 - EARNINGS DISTRIBUTION PERCENTILE RATIOS 


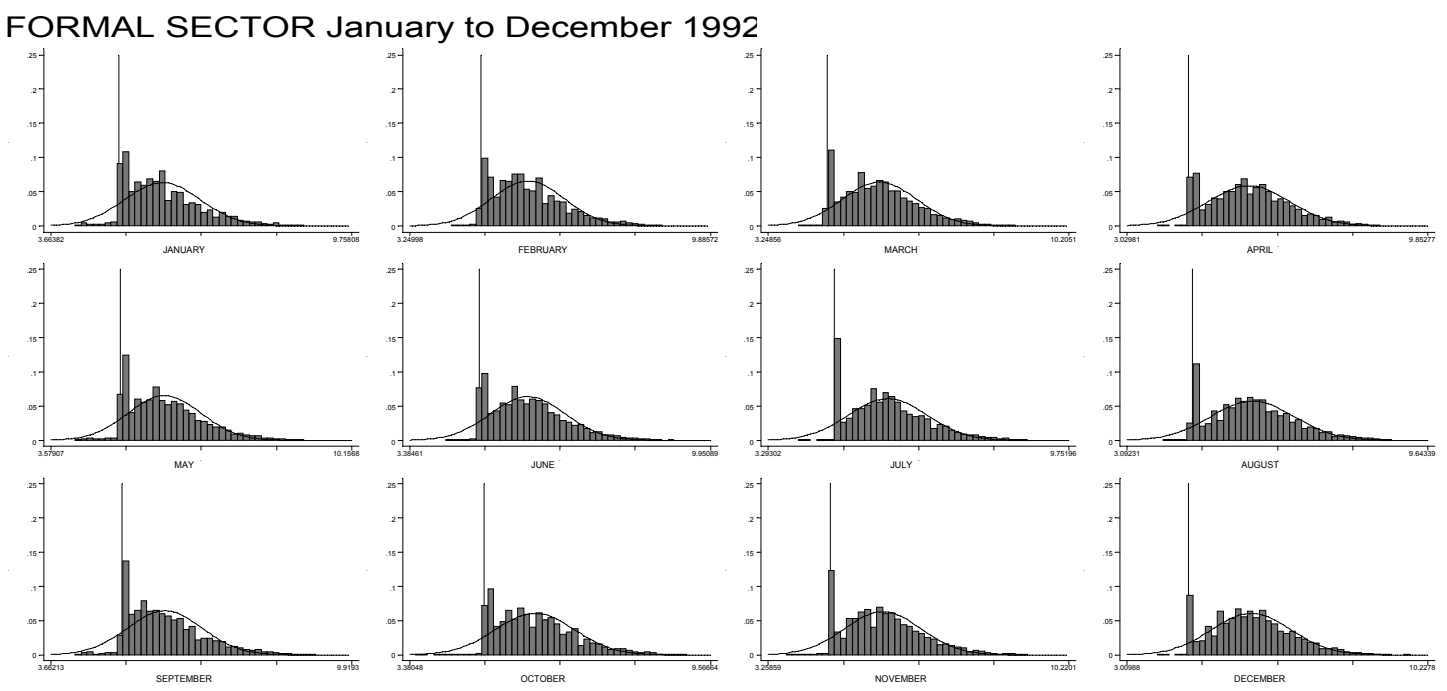

Graph 3.a - EARNINGS DISTRIBUTION 


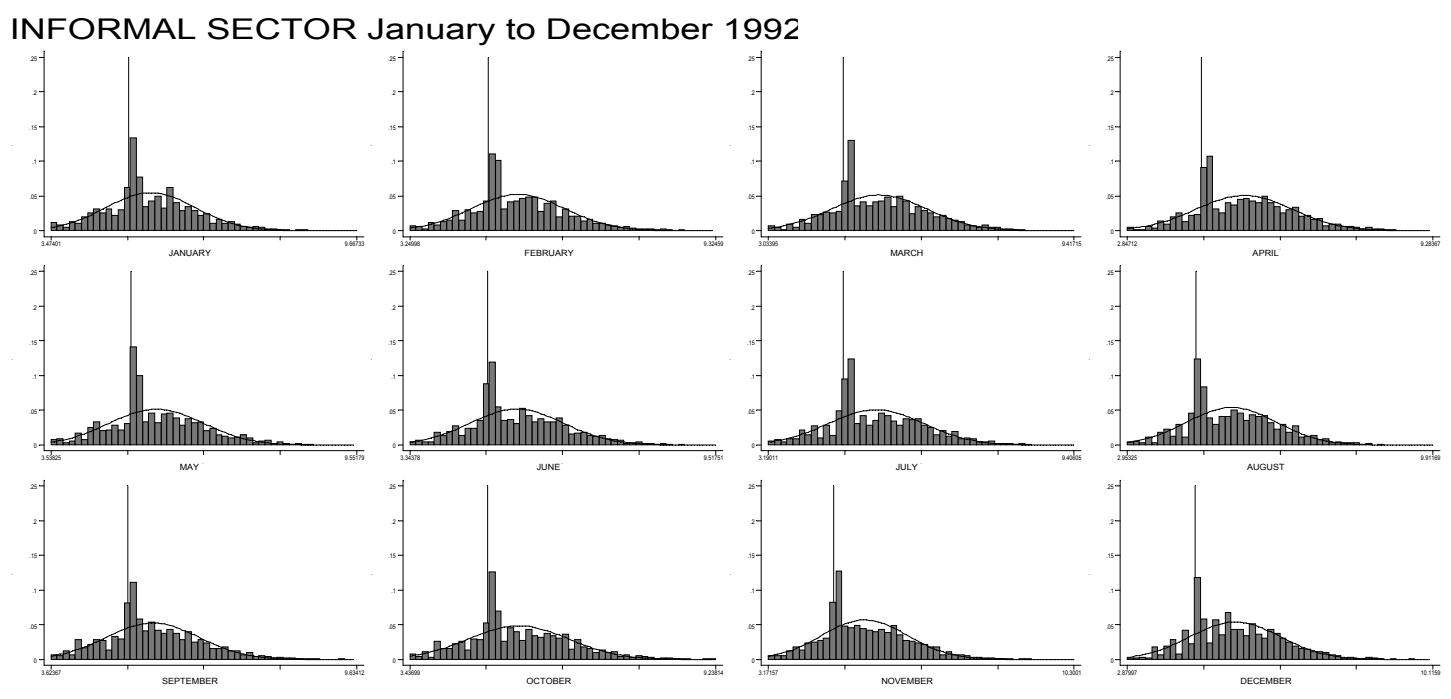

Graph 3.b - EARNINGS DISTRIBUTION

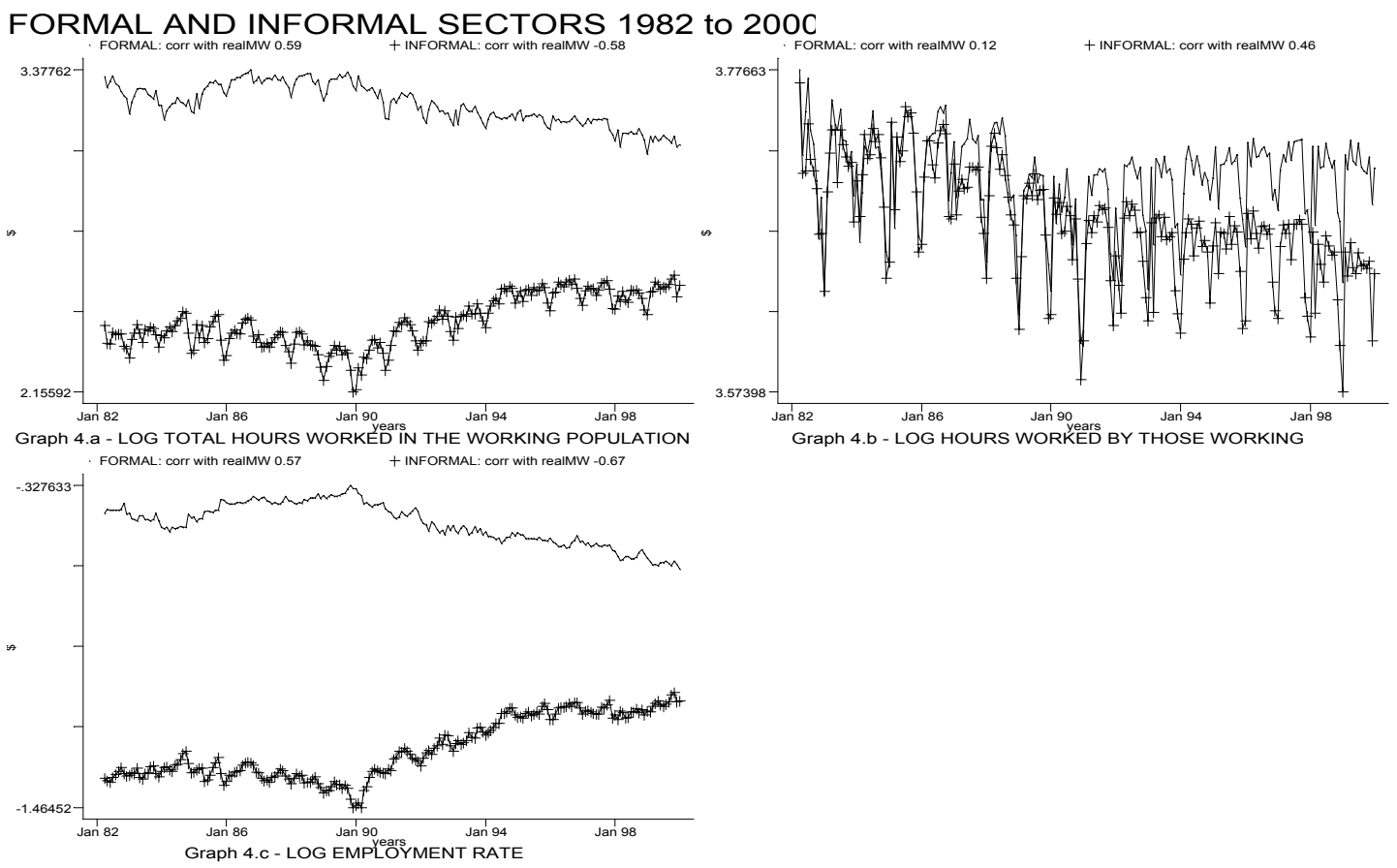

Graph 4 - HOURS WORKED AND EMPLOYMENT RATE 


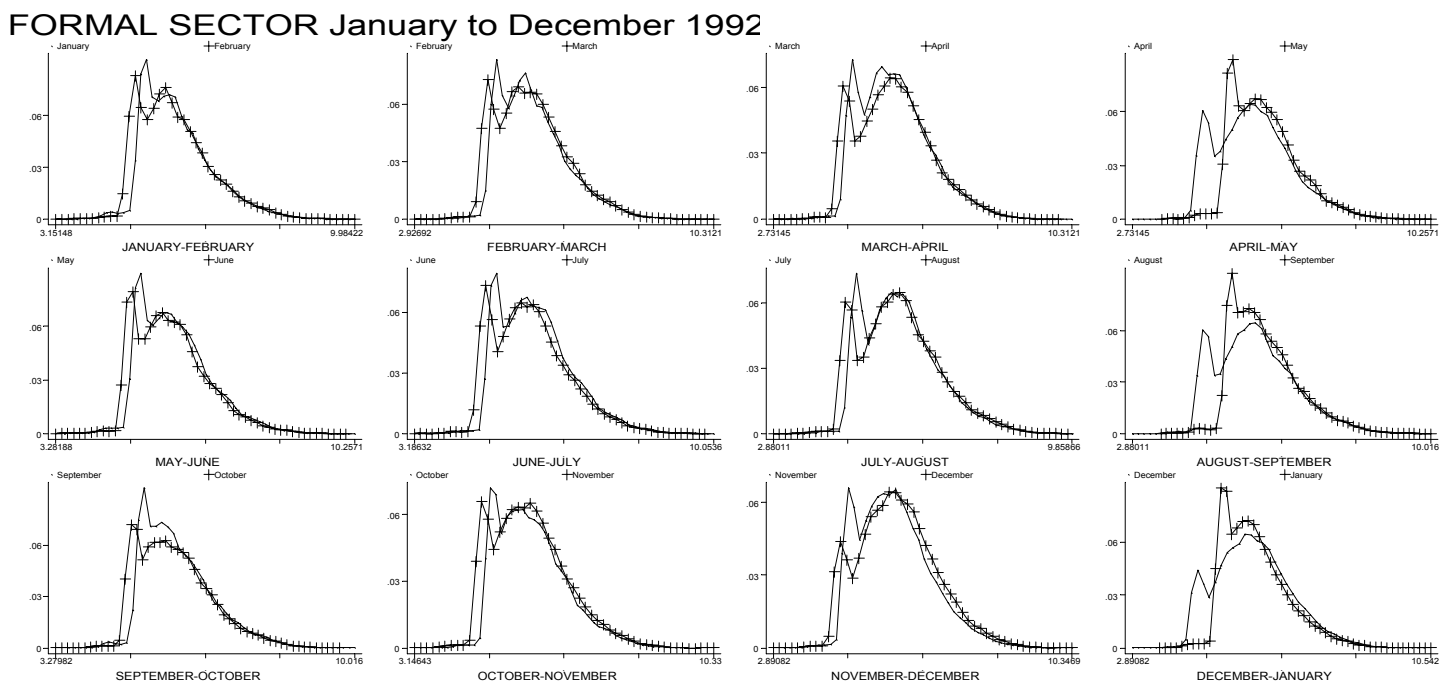

Graph 5.a - EARNINGS KERNEL DISTRIBUTIONS 


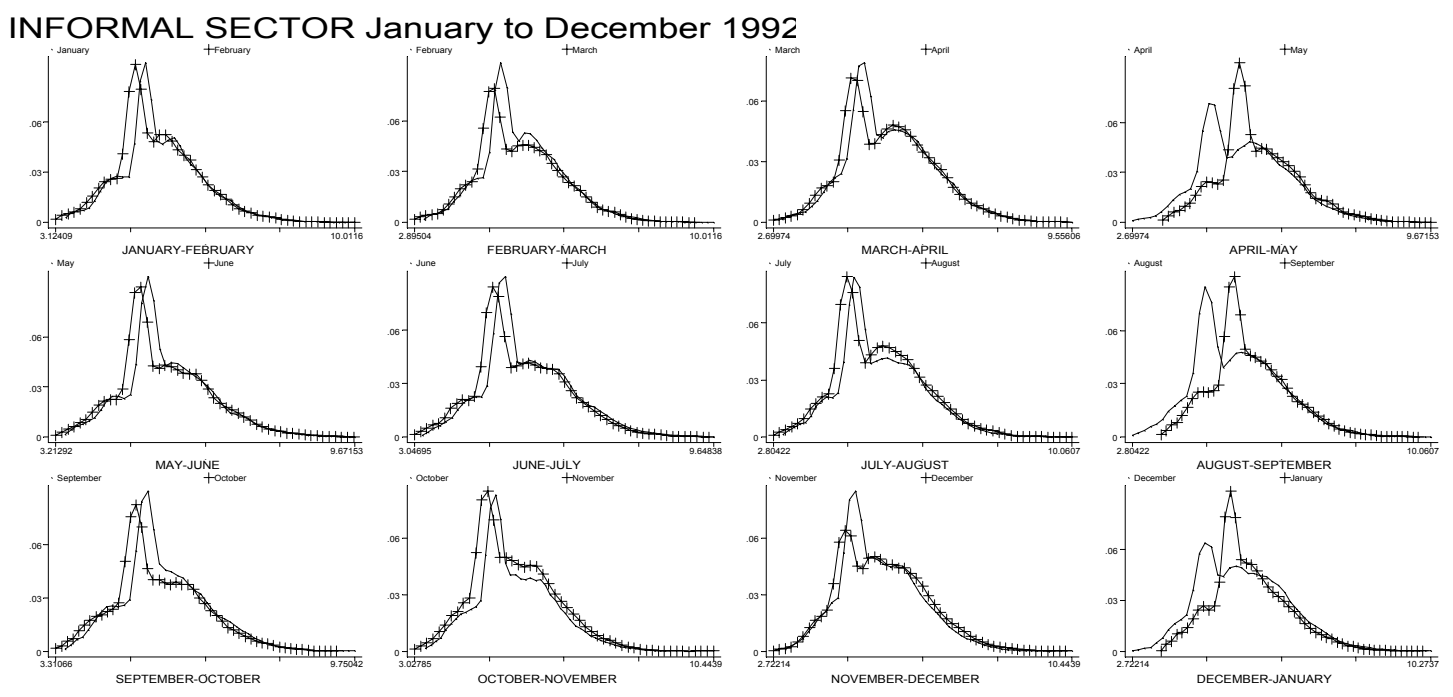

Graph 5.b - EARNINGS KERNEL DISTRIBUTIONS 
Table 1 - EFFECT OF A $10 \%$ INCREASE IN THE MINIMUM WAGE ON WAGES

\begin{tabular}{lcccc}
\hline percentiles & \multicolumn{2}{c}{ coef } & se & \multicolumn{2}{c}{ coef } & se \\
\hline & A - formal sector & B - informal sector \\
5th & $\mathbf{0 . 8 5}$ & 0.20 & $\mathbf{0 . 5 0}$ & 0.16 \\
10th & $\mathbf{0 . 4 9}$ & 0.18 & $\mathbf{0 . 5 2}$ & 0.17 \\
15th & $\mathbf{0 . 3 1}$ & 0.17 & $\mathbf{0 . 6 5}$ & 0.16 \\
20th & $\mathbf{0 . 0 5}$ & 0.16 & $\mathbf{0 . 4 3}$ & 0.15 \\
25th & $\mathbf{- 0 . 1 6}$ & 0.14 & $\mathbf{0 . 5 5}$ & 0.15 \\
30th & $\mathbf{- 0 . 2 2}$ & 0.12 & $\mathbf{0 . 3 8}$ & 0.16 \\
35th & $\mathbf{- 0 . 2 7}$ & 0.12 & $\mathbf{0 . 3 7}$ & 0.16 \\
40th & $\mathbf{- 0 . 2 2}$ & 0.10 & $\mathbf{0 . 1 7}$ & 0.15 \\
45th & $\mathbf{- 0 . 2 5}$ & 0.10 & $\mathbf{0 . 2 4}$ & 0.14 \\
50th & $\mathbf{- 0 . 3 0}$ & 0.10 & $\mathbf{0 . 1 7}$ & 0.14 \\
90th & $\mathbf{- 0 . 2 7}$ & 0.12 & $\mathbf{0 . 0 0}$ & 0.18 \\
95th & $\mathbf{- 0 . 1 2}$ & 0.13 & $\mathbf{- 0 . 0 8}$ & 0.20 \\
mean & $\mathbf{- 0 . 0 9}$ & 0.10 & $\mathbf{0 . 2 1}$ & 0.11 \\
90th/10th & $\mathbf{- 0 . 8 9}$ & 0.18 & $\mathbf{- 0 . 5 0}$ & 0.21 \\
90th/50th & $\mathbf{0 . 0 3}$ & 0.10 & $\mathbf{- 0 . 2 2}$ & 0.17 \\
50th/10th & $\mathbf{- 0 . 9 2}$ & 0.15 & $\mathbf{- 0 . 2 8}$ & 0.15 \\
st.deviation & $\mathbf{- 0 . 1 6}$ & 0.05 & $\mathbf{- 0 . 2 0}$ & 0.07
\end{tabular}

1) Percentile regressions are shown for selected percentiles, followed by percentile ratio and standard deviation regressions. The dependent variable is the various percentiles, ratios of percentiles and standard deviation of the wages distribution.

2) Time effects are modelled with year, seasonal-month, stabilization and 1988 structural break dummies. Controls are population and institutional factors (see Section 3.1).

3) The A panel shows estimates for the formal and the B panel for the informal secto.

4) To obtain the equivalent of a $10 \%$ increase in the minimum wage, the estimates of spike were multiplied by 0.3 . 
Table 2 - EFFECT OF A 10\% INCREASE IN THE MINIMUM WAGE ON EMPLOYMENT - model in levels

\begin{tabular}{|c|c|c|c|c|c|c|c|c|c|c|c|}
\hline \multirow[b]{2}{*}{$\begin{array}{l}\text { dependent } \\
\text { variable }\end{array}$} & \multirow[t]{2}{*}{ model } & \multirow{2}{*}{$\begin{array}{r}\text { static } \\
\text { sr coef } \\
(1) \\
\end{array}$} & \multicolumn{3}{|c|}{ dynamic } & \multirow{2}{*}{$\begin{array}{r}\text { Ir } \\
\text { Ir coef } \\
(3) \\
\end{array}$} & \multirow{2}{*}{$\begin{array}{r}\text { static } \\
\text { coef } \\
(1) \\
\end{array}$} & \multicolumn{3}{|c|}{ dynamic } & \multirow{2}{*}{$\begin{array}{r}\text { Ir } \\
\text { coef } \\
\text { (3) }\end{array}$} \\
\hline & & & se & $\begin{array}{r}\text { sr coef } \\
(2) \\
\end{array}$ & se & & & se & $\begin{array}{r}\text { coef } \\
(2) \\
\end{array}$ & se & \\
\hline & & \multicolumn{5}{|c|}{ A - formal sector } & \multicolumn{5}{|c|}{ B - informal sector } \\
\hline total employment & & 0.09 & 0.06 & 0.06 & 0.02 & 0.03 & 0.10 & 0.07 & 0.04 & 0.03 & 0.02 \\
\hline hours worked & & 0.12 & 0.05 & 0.10 & 0.02 & 0.06 & 0.24 & 0.03 & 0.21 & 0.03 & 0.18 \\
\hline employment rate & & -0.04 & 0.02 & -0.04 & 0.02 & -0.04 & -0.15 & 0.07 & -0.17 & 0.03 & -0.09 \\
\hline & & \multicolumn{5}{|c|}{ c - aggregate } & & & & & \\
\hline unemployment rate & & 0.30 & 0.22 & 0.21 & 0.10 & 0.13 & & & & & \\
\hline
\end{tabular}

1) The dependent variable is average hours worked for the working population, average hours worked for those employed and employment rate. Hours and Job elasticities add to Total elasticity.

2) Column 1 shows the base specification with past inflation, controls, region and time fixed effects; and column 2 adds dynamics to the base specification (24 lags of the independent variable). Column 3 shows the long run coefficient associated to the short run coefficient in column 2.

3) Time effects are modelled with year, seasonal-month, stabilization and 1988 structural break dummies. Controls are population and institutional factors (see Section 3.1).

4) Panels $A$ and $B$ show respectively estimates for the formal and informal sectors, and panel $C$ show unemployment estimates for the aggregate.

Each panel has four rows: (1) within groups (levels) and (2) first differences.

5) To obtain the equivalent of a $10 \%$ increase in the minimum wage, the estimates of spike were multiplied by 0.3

Table 3 - EFFECT OF A 10\% INCREASE IN THE MINIMUM WAGE ON EMPLOYMENT - model in first differences

\begin{tabular}{|c|c|c|c|c|c|c|c|c|c|c|}
\hline \multirow[b]{2}{*}{$\begin{array}{l}\text { dependent } \\
\text { variable }\end{array}$} & \multirow{2}{*}{$\begin{array}{r}\text { static } \\
\text { coef } \\
(1) \\
\end{array}$} & \multicolumn{3}{|c|}{ dynamic } & \multirow{2}{*}{$\begin{array}{r}\text { Ir } \\
\text { coef } \\
(3)\end{array}$} & \multirow{2}{*}{$\begin{array}{r}\text { static } \\
\text { coef } \\
(1)\end{array}$} & \multicolumn{3}{|c|}{ dynamic } & \multirow{2}{*}{$\begin{array}{r}\text { Ir } \\
\text { coef } \\
(3) \\
\end{array}$} \\
\hline & & se & $\begin{array}{r}\text { coef } \\
(2) \\
\end{array}$ & se & & & se & $\begin{array}{r}\text { coef } \\
(2) \\
\end{array}$ & se & \\
\hline & \multicolumn{5}{|c|}{ A- formal sector } & \multicolumn{5}{|c|}{ B - informal sector } \\
\hline total employment & 0.08 & 0.04 & 0.06 & 0.04 & -0.11 & 0.15 & 0.06 & 0.16 & 0.05 & -0.19 \\
\hline hours worked & 0.09 & 0.03 & 0.08 & 0.03 & -0.37 & 0.11 & 0.04 & 0.06 & 0.04 & 0.43 \\
\hline \multirow[t]{2}{*}{ employment rate } & -0.01 & 0.02 & -0.01 & 0.01 & -0.02 & 0.04 & 0.04 & 0.10 & 0.07 & 0.43 \\
\hline & \multicolumn{5}{|c|}{ c - aggregate } & & & & & \\
\hline unemployment rate & -0.08 & 0.15 & -0.30 & 0.16 & -0.07 & & & & & \\
\hline \multicolumn{11}{|c|}{$\begin{array}{l}\text { 2) Column } 1 \text { shows the base specification with past inflation, controls, region and time fixed effects; and column } 2 \text { adds dynamics to the base specification ( } 24 \\
\text { lags of the independent variable). Column } 3 \text { shows the long run coefficient associated to the short run coefficient in column } 2 \text {. } \\
\text { 3) Time effects are modelled with year, seasonal-month, stabilization and } 1988 \text { structural break dummies. Controls are population and institutional factors (see Section 3.1). } \\
\text { 4) Panels } A \text { and B show respectively estimates for the formal and informal sectors, and panel C show unemployment estimates for the aggregate. } \\
\text { Each panel has four rows: (1) within groups (levels) and (2) first differences. }\end{array}$} \\
\hline
\end{tabular}

